Article

\title{
Political Entrepreneurs and Pork-Barrel Spending
}

\section{J. Zachary Klingensmith}

Penn State Erie, The Behrend College, Black School of Business, 4701 College Drive, Erie, PA 16563, USA; jzk17@psu.edu

Received: 10 January 2019; Accepted: 20 February 2019; Published: 28 February 2019

\begin{abstract}
Pork-barrel spending is the use of federal money for localized projects that yield only a narrow geographic benefit. It is a commonly held belief that politicians use this spending to improve their chances of re-election. One way that an incumbent can increase their chances of re-election is through increased fundraising. Political entrepreneurs see this opportunity and attempt to benefit from these projects in exchange for campaign contributions. This paper investigates whether incumbents are able to use their position to bolster their campaign contributions. I find pork-barrel spending and political contributions to be positively related, but this effect is only present when the incumbent properly times the project. I also find that general federal appropriations do not have the same impact. This supports the claim that pork-barrel spending can be used as a currency in the marketplace for political capital.
\end{abstract}

Keywords: pork-barrel spending; campaign finance; incumbency advantage; elections

JEL Classification: D72; H50

\section{Introduction}

\subsection{Advertising, Credit-Claiming, and Position-Taking}

In his seminal work, Congress: The Electoral Connection, Mayhew (1974) claimed that members of Congress devote resources to three basic activities when seeking re-election. They can advertise through speeches, public openings, and campaign ads. They can credit-claim by showing off the positive things they have done for their constituents. This can include federal money appropriated to their district, or policies that have a net benefit for their voters. Finally, members of Congress can take positions by using their voting behavior to form a political platform.

Targeted expenditures, which are also called pork-barrel spending, allow incumbents to both credit claim and advertise simultaneously. They accomplish this through three channels. First, pork-barrel spending allows an incumbent to advertise by initiating pork-barrel projects that are visible and useful to the constituents. It is not surprising to see the legislator at the groundbreaking of a project or toting oversized scissors at a grand opening. Second, an incumbent can credit-claim if the pork-barrel spending results in improved economic conditions. If a constituent's life is improved through a pork-barrel project, that citizen is more likely to cast a vote for the incumbent. Third, an incumbent can increase their ability to advertise through campaign contributions. In this scenario, political entrepreneurs engage in rent-seeking behavior by making campaign contributions to incumbents in exchange for preferential treatment, including the funneling of pork-barrel money to prominent donors. For example, the owner of a concrete supplier may make a contribution to the incumbent's campaign, and in exchange, the donor receives a contract for a new sidewalk project in the district.

This paper focuses on the third channel. The main goal of this paper is to determine whether rent-seeking does in fact occur by estimating the effect that pork-barrel spending has on fundraising. While others have studied why politicians use pork-barrel spending, I use a novel approach to isolate 
one specific way that politicians use pork-barrel money to their benefit. To accomplish this goal, I test three hypotheses: first, whether pork-barrel spending has an impact on an incumbent's ability to fundraise, second, whether the timing of the pork-barrel appropriations matter, and third, whether general federal appropriations do not have the same impact on fundraising that pork-barrel spending does. If I can prove each hypothesis, then it provides evidence that political entrepreneurs are active in the political market for pork-barrel spending, and that incumbents are more than happy to go along with the process.

\subsection{Political Entreprenurs and Rent-Seeking}

A political entrepreneur is someone in the private sector that attempts to "change the direction and flow of politics" through the act of rent-seeking. Political entrepreneurs create inefficiencies in the market as they have "energies and talents that could be used elsewhere" (Schneider and Teske 1992). Instead of focusing their creative energies on enhancing the product or service they offer, they use that energy and capital in an attempt to change laws and encourage projects that would benefit their business.

By definition, those engaging in rent-seeking, including political entrepreneurs, attempt to redistribute gains to themselves in the absence of the creation of any new gains (Tullock 1967; Krueger 1974; Posner 1975; Tullock et al. 1980). Political entrepreneurs have an incentive to lobby for less regulations (or regulations that hurt competing industries) or for funding directed to projects that can benefit the entrepreneur, even at the expense of the population at large. Rent-seeking is viewed as "in-kind" where lobbyists use benefits such as fancy dinners and nice vacations to encourage beneficial legislative changes (Mixon et al. 1994). Additionally, lobbyists can attempt to spur legislative change through the use of indirect rent-seeking, where special-interest groups attempt to influence legislation "by holding demonstrations, purchasing billboard, radio, or television advertising, or by funding, publishing, and circulating policy-oriented journals and research (the type of activity usually done by public policy institutes)" (Sobel and Garrett 2002). While exchanging political favors for campaign contributions is not technically bribery, it is a form of in-kind rent-seeking. Past studies have shown that the effect of rent-seeking can be as large as $22 \%$ of gross national product. (Laband and Sophocleus 1988).

As is the case in the private market, the political entrepreneur must realize that a profit opportunity exists, and must be willing to take action as they would in a private market (Holcombe 2002; McCaffrey and Salerno 2011). The end result is a system of political capitalism where the political elite and the economic elite cooperate in a way that is mutually beneficial (Holcombe 2015). Therefore, both the politicians and the political entrepreneurs have motivation to work together while engaging in this rent-seeking behavior. For the politician, this creates a scenario where the politician may betray their political beliefs to gain political capital for future use (Lopez 2002). This can include "calling in favors", such as campaign donations, from those that have benefited from policies and projects made possible by the legislator.

\subsection{Pork-Barrel Spending and Campaign Contributions}

Pork-barrel spending is defined as federal appropriations used to fund localized projects that yield concentrated geographical benefits. There has been an abundant number of papers published attempting to identify why legislators are so motivated to use pork-barrel money. Only a handful are mentioned below. However, if pork-barrel spending can increase campaign contributions, that by itself is a sufficient reason to expend resources to seek it. A long series of studies have shown that campaign expenditures are directly related to success in an election (Dawson and Zinser 1976; Jacobson 1981, 1990; Palda 1973, 1975; Samuels 2002; Stratmann 2013; Welch 1974, 1976). This is even more important to incumbents facing a tight election. While campaign fundraising is typically more important to challengers, as they must overcome the incumbency bias (Jacobson 1990), political organizations are able to aid marginal incumbents from potentially damaging economic forces through 
additional campaign funding (Jacobson 1981). Therefore, political entrepreneurs may be able to identify incumbents in the greatest need, and more importantly, those most willing to cooperate in exchange for said campaign contributions.

Returning to the earlier theme of the paper, the use of pork-barrel spending would simultaneously allow a legislator to engage in two types of re-election activity: credit-claiming and advertising. When a legislator directs pork-barrel projects to those that return the favor through campaign contributions, they are engaging in credit-claiming. At the same time, those political contributions can be used for additional advertisements such as radio and television commercials.

The link between campaign contributions and corporate gains is largely anecdotal in the United States (Milyo 1999; Stratmann 1995); however, empirical evidence of this effect has been shown in other countries such as Brazil (Boas et al. 2014). For example, in 1993, individual members of the Brazilian congressional Joint Budget Committee accepted kickbacks of up to $3 \%$ of a project's value in compensation for their assistance in funding approval (Boas et al. 2014; Krieger et al. 1994). Even more recently, Andrade Gutierrez, one of the largest construction companies in Brazil, increased its contributions in municipal elections from nearly $\$ 75,000$ to $\$ 37.1$ million. At the same time, the company was awarded nearly $\$ 3$ billion in construction contracts associated with the 2014 World Cup (Payne 2014). It should be noted that the Brazilian political system is often seen as an anomaly, and may not be directly comparable to the American political system. At the same time, the motivations that exist within the Brazilian political system are the same as those that exist in the American political system.

Pinpointing the relationship between corporate gains and fundraising in the United States has been problematic for many reasons. First, due to campaign finance laws, corporations can only donate money to political action committees (PACs), which then use the money to support a politician or issue. Records of contributions to PACs are less detailed than those that record donations to candidates, and therefore, it is difficult to measure corporate efforts to support incumbents. Moreover, the links between corporate gains and public policy is rarely obvious.

Although it tends to be difficult to link corporate profits to national programs, this problem is reduced for the case of targeted expenditures. Pork may be presumed to have the greatest effect on the profits of firms in the district receiving the expenditures. Potential donors benefit both from contracts to produce the services provided, necessary infrastructure for those projects, and indirectly through expenditures by firms and their employees in the district of interest.

Of course, legislators may also attempt to use general appropriations to their advantage. Federal aid programs are much larger than targeted expenditures. However, legislators have a more difficult time claiming credit for general government spending. This is not to say that a legislator that pioneered major changes to a national program cannot claim credit. Instead, voters are not likely to give credit to their legislator for an annual increase in Social Security benefits or additional highway spending. This is both because a single legislator's vote is rarely decisive, and because many general federal appropriations are formula-based, so individual legislators have very little control over the amount of money that each state receives. As a consequence, large federal programs are very difficult to change in a manner that generates state or district-specific benefits.

\section{Methodology}

\subsection{The Model}

Given the extensive research conducted on political fundraising and the effects of campaign spending, there has been surprisingly little research on the effects of pork-barrel spending on campaign contributions. Samuels (2002) found that increased pork-barrel spending leads to an increase in incumbent fundraising, all other things being equal, in the Brazilian political system. Then, the additional campaign contributions are used to increase the likelihood of re-election. However, his work does not address the mechanism through which pork-barrel spending increases prospects for electoral 
success. This paper attempts to address this by examining the link between pork-barrel spending and incumbent fundraising.

While Samuels (2002) posited that pork-barrel spending increases fundraising, Stratmann (2013) contended that fundraising tends to increase pork. My results suggest that Stratmann has misidentified the relationship. Specifically, I find that an increase in pork-barrel spending leads to more campaign contributions. One possibility for the difference is that Stratmann's work focuses on the House of Representatives, whereas my work focuses on the Senate. Senators have more direct influence over public policies, including the appropriation of pork-barrel monies, than members of the House. Their six-year terms allow senators to reap benefits that may take longer to develop compared to the two-year terms for representatives. Moreover, states are able to capture a larger percentage of the benefits of any given project compared to that of a congressional district. While projects in a congressional district may benefit a small handful of companies within the district, those benefits will spill over into neighboring districts through the effects of sub-contracting, commuting, and shopping across district boundaries. Therefore, the state is able to capture most of the benefits from a given pork-barrel project, compared to only a portion at the district level.

This study is not without limitations. There is one significant disadvantage associated with a state-level analysis as opposed to that of a district-level study. There are two senators per state elected at-large. Therefore, it is impossible to untangle the effort of each senator. Further, it is also impossible to separate the efforts of the senators from the efforts of representatives who also exerted energies to obtain the funding. This implies that the Samuels and Stratmann's framework can be applied at the state-level only after several modifications are adopted. A more thorough look at the two senator problem will be addressed later in this paper.

I use a fundraising model based on Samuels (2002), Krebs (2001), and Bonneau (2007) for the purposes of estimation. The Samuels (2002) model estimates the percentage of campaign finance in a Brazilian state based on factors such as previous electoral success, number of terms served, and party leadership. Krebs (2001) analyzed fundraising in city council elections, and Bonneau (2007) addressed the determinants of fundraising in state Supreme Court elections. While the last two papers are not conducted at the federal level, many of the determinants still apply, regardless of the level of government being discussed.

This study extends Samuels's (2002) paper and complements Stratmann's (2013) approach in the following ways. First, the present study focuses on United States Senate elections from 2004 to 2018, rather than a single election. For three years, it was possible to trace pork-barrel spending to the individual representative responsible for its appropriation. Due to changes in reporting rules and a moratorium on pork-barrel spending starting in 2011, data can no longer be collected at the district level. Therefore, in order to examine a longer time period, the state level must be used. While there is an effort to use machine learning to allow artificial intelligence to identify pork-barrel spending deep within spending bills ${ }^{1}$, that type of data is not currently available.

Second, unlike the Samuels (2002) paper, this paper focused on the United States. As mentioned, there are major differences between the American and Brazilian political systems, especially with respect to the acceptance of financial kickbacks. However, incumbents face the same pressures to utilize whatever means necessary (and legal) in order to be re-elected.

Finally, this study focuses on the Senate, unlike the work of Krebs (2001), Bonneau (2007), and Stratmann (2013), which examine other levels of government. If a linkage between campaign fundraising and pork-barrel spending is found, then it is entirely plausible that this is evidence of pork-barrel spending being used as political capital. This would reinforce the idea of pork-barrel spending being used for both advertising and credit-claiming.

1 https://dssg.uchicago.edu/2014/12/04/using-data-for-a-more-transparent-government/. 
The general model that I use is as presented follows:

$$
\text { fundraising }=\beta_{0}+\beta_{i} \cdot \text { pork }+\beta_{j} \cdot \text { electoral variables }+\beta_{k} \cdot \text { year }+\epsilon
$$

where fundraising is one of the two dependent variables used to measure the incumbent's ability to fundraise, pork is one of the variations of federal appropriations, electoral variables are control variables concerned with the political attributed of the incumbent, year are time variables, and $\epsilon$ is the error term. I discuss each type of variable in more depth below.

\subsection{Fundraising Data}

There are two dependent variables used in this study.

\subsubsection{Incumbent Fundraising (in Millions of Dollars)}

The first dependent variable is the total amount of money raised by the incumbent in millions of dollars during the election cycle as in Krebs (2001) and Bonneau (2007). This data is collected from the Center for Responsive Politics' Open Secrets.

\subsubsection{Share of Fundraising}

The second dependent variable is the share of fundraising is the percentage of the overall fundraising the incumbent accounted for in their specific race. For example, if the incumbent raised $\$ 7$ million and the challenger raised $\$ 3$ million, then the incumbent would have a $70 \%$ share of the fundraising, as they raised $\$ 7$ million of the $\$ 10$ million total raised in that specific electoral battle. Both Samuels (2002) and Stratmann (2013) used the share of fundraising variable. The share of fundraising has several advantages over the total fundraising variable. First, population does not matter when the share of fundraising is used, as it is simply a percentage of total fundraising. In addition, price level differences do not matter. Since the spending in Senate campaigns can vary drastically, the fundraising advantage variable allows for a more straightforward comparison of Senate races. The fundraising data are also collected from the Center for Responsive Politics' Open Secrets.

\subsection{Pork-Barrel and Appropriations Spending Data}

Data on the incumbent was collected for all senators vying for re-election from 2004-2018. Pork-barrel spending data is collected in two ways: aggregated by election cycle and disaggregated by the year within the election cycle.

\subsubsection{Total Pork-Barrel Spending}

Data on pork-barrel spending are taken from the Citizens against Government Waste (CAGW) dataset. The first variable measures the total amount of pork-barrel spending appropriated by the Senator's state during their six-year term. The data are presented in millions of dollars. I hypothesize that there will be a positive correlation between fundraising and pork-barrel spending. One potential issue is that if the timing of pork-barrel spending matters, then the relationship may be ambiguous.

\subsubsection{Pork-Barrel Spending by Year}

I also use a set of annual pork-barrel spending variables. The pork-barrel spending appropriated to a state is linked to electoral cycles, rather than years per se. For instance, if a Senator was up for re-election in 2008, I compute the amount of pork-barrel spending that went to the state from 2003-2008, both annually and in aggregate. This allows for a determination as to whether the timing of pork-barrel spending impacts campaign contributions. Specifically, I test to determine whether the pork-barrel spending appropriated in election years impacts fundraising. Since Senate terms are six years long, data from 1999-2018 is used. Since it is impossible to distinguish between the individual efforts of each senator, the total amount of pork-barrel spending appropriated by the state is used. Due 
to the inability to disaggregate, it is likely that free riding is occurring within the Senate (Rogers 2002). As mentioned earlier, even though a district-level study would yield stronger results, there are 20 years of pork barrel spending data available at the state level, but only three years of data at the district level.

To help illustrate the election cycles, I graph the average amount of pork-barrel spending from each "year to election" in Figure 1. In Figure 1 below, it is apparent that pork-barrel spending follows a political election cycle, as it spikes every two years, which corresponds with the Senate elections. I have included two different iterations of the data on the figure below. The bars on the left are the average pork-barrel appropriations from 1999-2018, whereas the bars on the right are the average pork-barrel spending from 1999-2010. The reason for this distinction is a 2011 Congressional moratorium on pork-barrel spending. The amount of pork-barrel spending has fallen drastically. The total pork-barrel spending by year is shown in Figure 2. The effect of the moratorium is apparent starting in 2011.

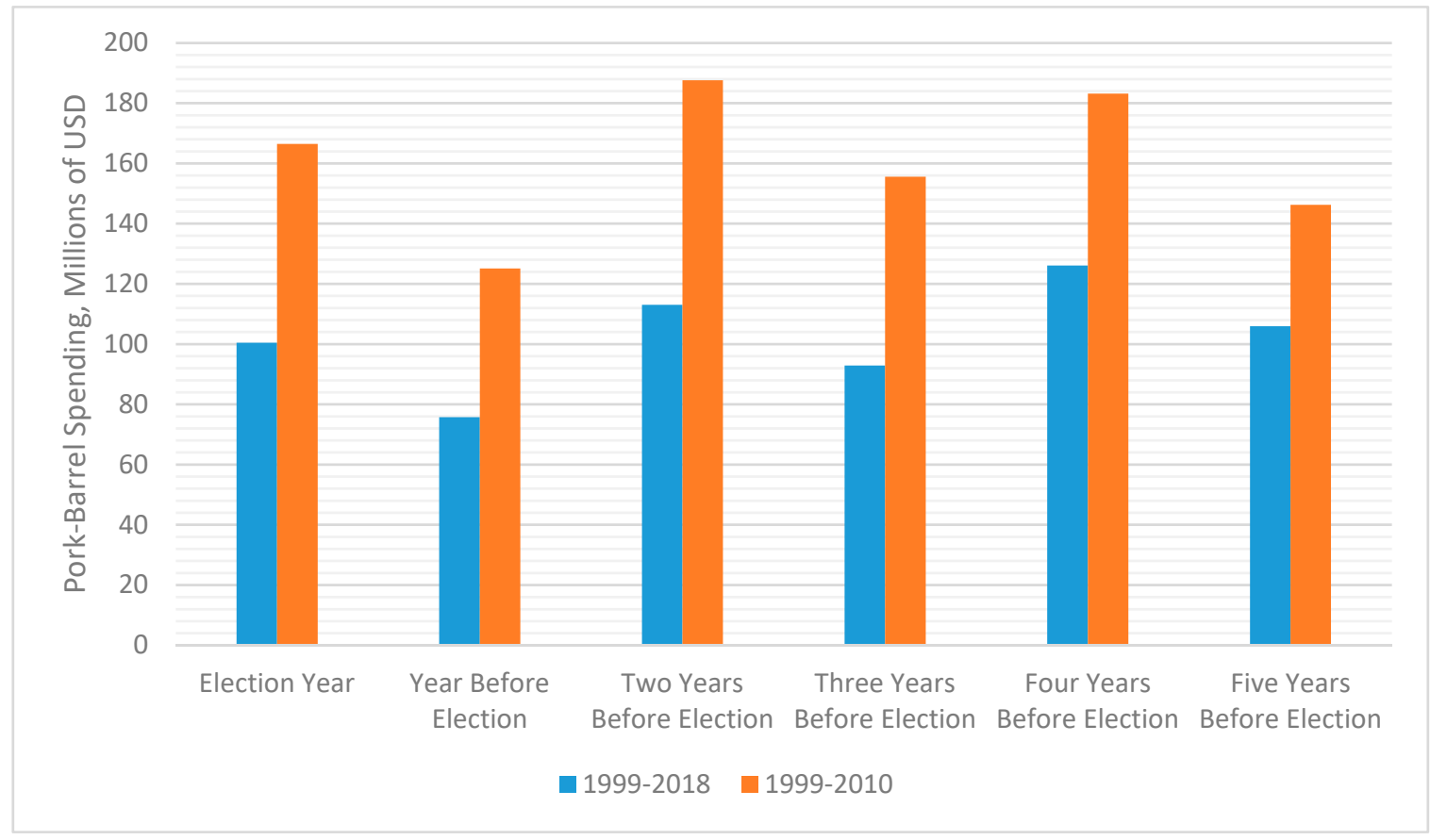

Figure 1. Pork-Barrel Spending by Year.

Various estimations have shown that pork-barrel spending appropriations in non-election years have no statistical impact. Therefore, for the purposes of this study, I use the pork-barrel spending appropriated in years with Senate elections. It is expected that there is both a "what have you done for me lately" attitude from both parties, in addition to some degree of interference being picked up due to the specification of the variable. Again, it is problematic that state-level data is being used as opposed to district-level data, as it is impossible to disaggregate the efforts of the two Senators. However, district-level data is not available for more than three years.

To determine whether and to what degree pork-barrel appropriations impact fundraising, two series of estimates are undertaken for each dependent variable. First, aggregated pork-barrel spending and the other control variables are used to estimate the total amount of funds raised by the incumbent. Next, the possibility of an electoral cycle in pork and pork-induced donations are estimated using annual data for the three election years during each senator's term. The inclusion of annual values also explores whether timing is important when considering the effects of pork-barrel spending on future fundraising. 


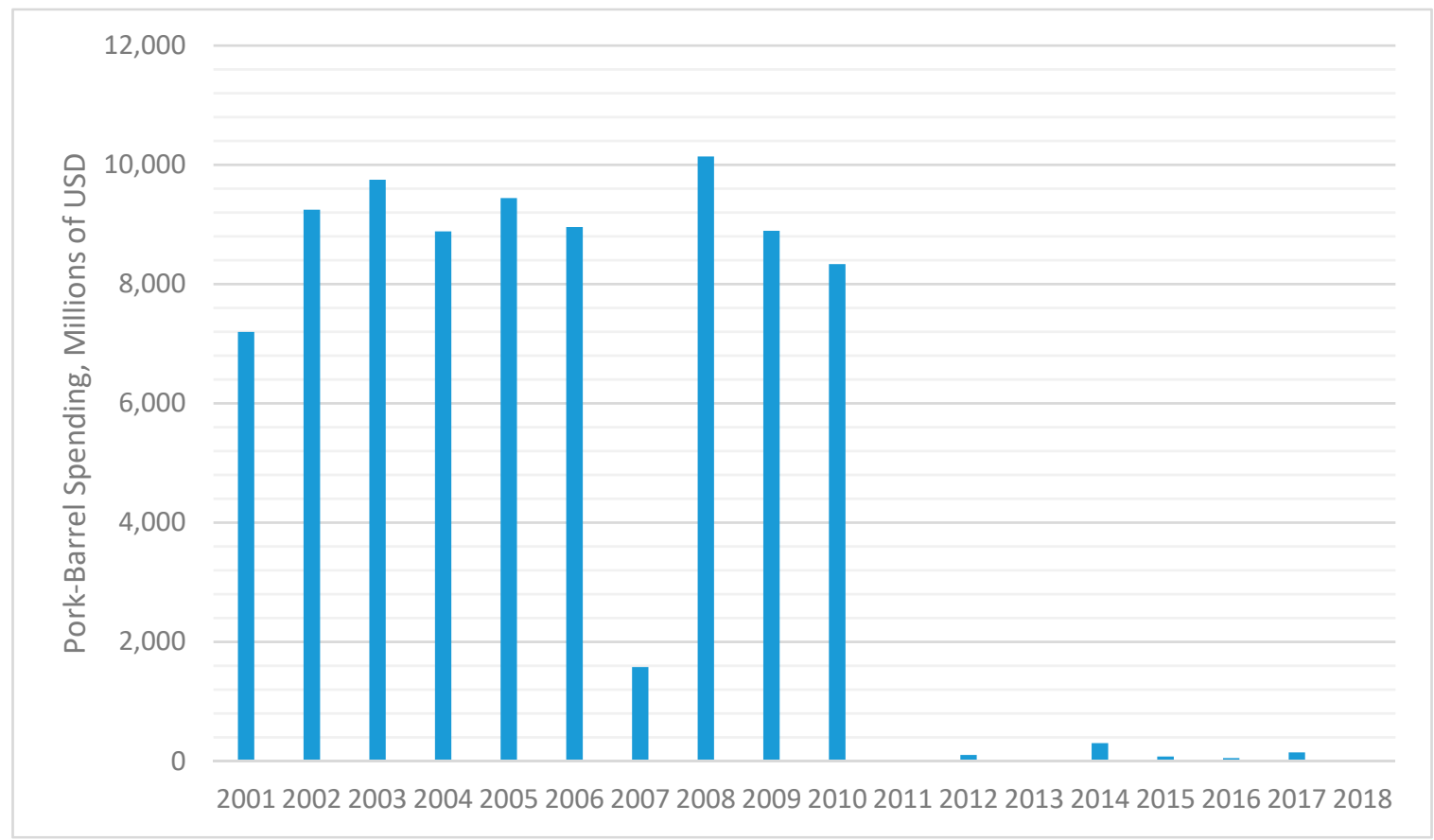

Figure 2. Pork-Barrel Spending by Year.

\subsubsection{Federal Aid}

In order to assess differences between the impacts of pork-barrel spending and general appropriations on fundraising, I use a federal aid variable from the United States (US) Census. This variable measures the amount of federal aid appropriated to each state. The federal aid is calculated by federal outlays to states from a variety of federal agencies. The data are collected from the United States Census Statistical Abstracts of the United States, and specifically from the section titled "Federal Aid to State and Local Governments-Selected Programs by State". The Federal Aid variable does not include Social Security or Medicare. In addition, I removed Medicaid spending, since it is also formula-based. As was the case with pork-barrel spending, two forms of this variable are used. The first is the aggregate federal appropriations in billions of dollars during the Senator's six-year term. The second is the annual, disaggregated federal appropriation in the years prior to an incumbent's re-election year. Unfortunately, due to budget cuts, the US Census no longer collects these data. As a result, the regressions that use federal appropriation data are restricted to 2004-2010.

It should not be surprising that federal aid can also be used by political entrepreneurs to manipulate the political process. Even though I hypothesize that pork-barrel spending will have a more intense impact on the ability to fundraise, past research has found federal aid being used for political reasons as well. For example, one study found that states can move their caucus/primary dates in order to obtain additional federal grants by making their primary/caucus more important (Mixon and Hobson 2001).

By using the appropriations variable in addition to the pork-barrel spending variables, I am able to determine whether general appropriation spending has the same impact on fundraising as pork-barrel spending. If pork-barrel spending is shown to be more effective, then the estimates provide an explanation for the attraction to pork-barrel spending.

\subsection{Characteristics of the Incumbent}

Characteristics of individual senators were also collected. I only use incumbents who served a full term. Therefore, senators who were appointed during the previous term or won a special election are not included, as they did not have the full six years to obtain funding. From 2004-2018, 196 incumbents 
met these criteria, and were included. The descriptive statistics and the sources for the dataset are shown in Table 1.

\subsubsection{Challenger Fundraising}

When an incumbent feels challenged, they must increase their efforts to fundraise. One way to determine the competiveness of the election is by considering how much the challenger fundraised. Similar to the other fundraising data, the amount the challenger fundraised comes from Open Secrets. I hypothesize that the more the challenger fundraised, the more vulnerable the incumbent was, and thus, the more the incumbent would need to fundraise to stave off the added competition.

\subsubsection{Cash-on-Hand}

The amount of cash-on-hand is included since it can influence the need to fundraise. I hypothesize that an incumbent with more cash-on-hand will need less campaign contributions.

\subsubsection{Performance in Previous Senate Election}

The percent of the vote received in the previous election is used to gauge the vulnerability of the candidate. These data are collected from the Federal Election Commission (FEC). Candidates that win elections by large margins do not need to raise large amounts of money, since they are not vulnerable. For example, Robert C. Byrd never received less than $60 \%$ of the vote in a general election. At the same time, because he was never vulnerable, he didn't need to exert resources or energy on serious fundraising. The most that Byrd ever needed to raise was $\$ 5$ million in his bid for re-election in 2006 (with many years needing $\$ 1$ million or less.) Since his passing, the same seat has required more than $\$ 10$ million in campaign financing. On the other hand, nearly $\$ 125$ million was raised during the Cruz/O'Rourke Senate election battle in 2018. Therefore, I hypothesize a negative relationship between past performance and incumbent fundraising.

\subsubsection{Number of Terms Served}

This variable counts the number of full terms served by the incumbent in the United States Senate. Similar to the previous variable, this variable measures the vulnerability of the seat. Senators that have held the seat for a longer period of time often have more name recognition. Therefore, I hypothesize a negative relationship between the number of terms served and campaign fundraising. It is possible that the relationship will not be as strong, since there is often a push to "drain the swamp" and "stop career politicians", which could be a detriment to longer-serving Senators.

\subsubsection{Democrat}

This is a binary variable that has a value of one if the incumbent is a Democrat. This variable measures the impact of the incumbent's party on the incumbent's ability to fundraise. Historically, the Republican Party is thought to be connected to the super rich, and more likely to obtain campaign funds. However, in my dataset, the average raised by the Democrat is $\$ 13.53$ million per election, compared to $\$ 10.77$ million per election raised by Republicans. Therefore, I anticipate a positive relationship between the Democrat variable and campaign fundraising.

\subsubsection{Do the Senators Belong to the Same Party?}

The next variable is another binary variable that has a value of one if the two senators belong to the same party. If a state is red or blue, the two senators can work together under the party name to advance their own re-election campaigns. On the other hand, senators may have a tougher time in a purple state, since they may also need to compete against the state's other senator. In addition, Senators in purple states are more likely to be vulnerable, as there is less voter allegiance to 
a single party. Therefore, I hypothesize a positive relationship between the same party variable and campaign fundraising.

\subsubsection{Female}

The final incumbent characteristic variable is a binary variable with a value of one if the incumbent is female. There has also been some debate over whether or not females have greater difficulty in raising funds due to the historical male-dominated environment of the United States political system (Uhlaner and Schlozman 1986). More recent research has suggested that those differences may have been eliminated over the past few decades with sex no longer having an impact on electability (Hayes and Lawless 2015). The only issue that seems to remain is that news coverage still tends to rely on male experts, which could lead to a bias against females (Freedman and Fico 2005). Therefore, I hypothesize a positive relationship between the female variable and incumbent fundraising, because females may need additional fundraising to overcome the remaining bias.

\subsection{Time Variables}

The final set of variables are time-based binary variables ranging from 2004 to 2016 (with 2018 being the omitted year). These variables are meant to measure any idiosyncratic differences between different election cycles.

Table 1. Descriptive Statistics for State-Level Regression.

\begin{tabular}{|c|c|c|c|c|c|c|}
\hline Variable & Source & Obs. & Mean & St. Dev. & Min & Max \\
\hline \multicolumn{7}{|l|}{ Dependent Variables } \\
\hline Incumbent Fundraising (millions of \$) & OpenSecrets & 196 & 12.25 & 8.47 & 1.7 & 51.57 \\
\hline Fundraising Advantage (in \%) & OpenSecrets & 196 & 78.59 & 19.28 & 17.33 & 100 \\
\hline \multicolumn{7}{|l|}{ Explanatory Variables } \\
\hline Challenger Fundraising (millions of \$) & OpenSecrets & 196 & 5.97 & 10.68 & 0 & 85 \\
\hline Cash-on-Hand (millions of dollars) & OpenSecrets & 196 & 1.68 & 2.68 & 0 & 17.16 \\
\hline Total Pork-Barrel Funding (millions of \$) & CAGW & 196 & 613.99 & 697.59 & 0 & 3640.2 \\
\hline Pork-Barrel Funding during Election Year & CAGW & 196 & 100.43 & 142.23 & 0 & 733.63 \\
\hline Pork-Barrel Funding Two Years Prior & CAGW & 196 & 113.05 & 140.26 & 0 & 671.8 \\
\hline Pork-Barrel Funding Four Years Prior & CAGW & 196 & 126.04 & 144.46 & 0 & 733.63 \\
\hline Total Federal Aid (Billions of \$) & Census & 101 & 40.21 & 55.96 & 1.1 & 296.4 \\
\hline Federal Aid during Election Year & Census & 101 & 9.59 & 12.04 & 1.2 & 66.6 \\
\hline Federal Aid Two Years Prior & Census & 101 & 8.43 & 10.51 & 1.1 & 53.8 \\
\hline Federal Aid Four Years Prior & Census & 101 & 7.42 & 9.12 & 0.9 & 46 \\
\hline$\%$ of Vote in Previous General Election & FEC & 196 & 60.06 & 9.41 & 36.08 & 100 \\
\hline Number of Terms in Current Office & Congress & 196 & 2.33 & 1.60 & 1 & 8 \\
\hline Are Senators from Same Party? ${ }^{*}$ & Congress & 196 & 0.709 & 0.455 & 0 & 1 \\
\hline Female ${ }^{*}$ & Congress & 196 & 0.209 & 0.408 & 0 & 1 \\
\hline Democrat * & Congress & 196 & 0.536 & 0.5 & 0 & 1 \\
\hline
\end{tabular}

* Variables marked with an asterisk are binary variables.

\section{Results}

\subsection{Results}

The first regression used a pooled ordinary least squares regression (OLS) approach to estimate total fundraising. The second estimate utilized the yearly pork-barrel appropriations during the election year and two years prior in lieu of the total, six-year pork-barrel appropriations. Regressions three and four replicated the first two regressions using the share of fundraising variable in place of the total fundraising variable.

Next, the same four regressions were repeated using federal aid to states instead of pork-barrel appropriations. Regression five used the six-year federal outlays, while regression six replaced the aggregate appropriation with annual outlays during the election year and two year prior in order to explore the possibility of an electoral cycle in the effects of state appropriations on overall fundraising. 
Finally, regressions seven and eight replicated regressions five and six using the share of fundraising variable in place of the total fundraising variable.

Unlike the work of Samuels (2002) and Stratmann (2013), the present study includes federal elections from 2004 to 2018 instead of a single election cycle. Therefore, panel estimation techniques can be used. Each of the eight regressions above were repeated using a fixed-effect panel approach as well.

\subsection{OLS Estimates of Fundraising with Pork-Barrel Spending}

Table 2 displays the results of the pooled OLS estimates of both total fundraising (regressions one to two) and share of fundraising (regressions three to four), including both the aggregate pork-barrel appropriations and the yearly pork-barrel appropriations. For regressions one and two, the challenger fundraising variable is both significant and positively correlated with pork-barrel spending in their states. In addition, cash-on-hand and the log of the population are all significant and correlated with incumbent fundraising.

Most of the variables behaved as expected. For example, pork-barrel spending appropriated during the election year has a positive and statistically significant relationship with the total amount of money fundraised. At the same time, no such relationship occurs between pork-barrel spending and the incumbent's share of fundraising. One possible explanation is that an incumbent reacts to the degree of threat from the challenger. For instance, an incumbent with a low likelihood of being unseated does not need to worry about fundraising. Yet, they are likely to control a large percentage of the total fundraising, as a weak challenger is not able to fundraise. On the other hand, in a highly competitive race, the incumbent may have to use pork-barrel spending to increase total fundraising. However, even with the additional fundraising, the share is unaffected due to the higher fundraising level by the challenger.

The female variable is statistically significant and positively related to total fundraising. As discussed earlier, female performance is elections have become essentially equalized with male performance, but there is still evidence of barriers to overcome in terms of public perception.

Regressions three and four used the share of fundraising as the dependent variable. The time effects were not included, because we do not have to control for things such as price levels. In addition, challenger fundraising is not included, since it is already part of the share of the fundraising variable. As was the case with the first two regressions, the cash-on-hand variable is significant. Unlike the first set of regressions, the previous general election performance is positively correlated with share of fundraising. This again makes sense, as a relatively unchallenged incumbent will not need to fundraise (explaining the negative relationship between total fundraising and past election performance), but does not have a serious challenger. The end result is an incumbent with a low-level of total fundraising, but a high percentage of the total fundraising share.

The 'same party' variable is positive and significant. This shows that when both senators belong to the same party, the incumbent up for election enjoys a larger share of the total fundraising. This again makes sense in terms of the competitiveness of the seat. If both senators belong to the same party, it is likely that the state is either a deeper red or blue, indicating a greater degree of safety. When senators serve in a purple state, they tend to be far more vulnerable.

\subsection{OLS Estimates of Fundraising with Federal Appropriations}

The next four regressions replicate the first four, this time using federal aid to states as opposed to the more specific pork-barrel spending. As discussed, due to a reduction in federal funding, the US Census stopped collecting the federal outlay data after 2010. Therefore, these regressions cover the Senatorial general elections from 2004-2010. The results are displayed in Table 3. For each of the regressions, the control variables behave in much the same way as they did in regressions one to four, so I will not repeat the results. The main difference between pork-barrel spending and federal aid is that there is no significant relationship between federal aid and fundraising other than the federal aid 
appropriated during the election year, which is actually negatively correlated with total fundraising. These results support the hypothesis that general federal appropriations do not have the same impact on fundraising. Even when federal spending such as Social Security, Medicare, and Medicaid are excluded, there is still no discernable linkage between federal aid spending and fundraising.

Table 2. Pooled OLS Regressions using Federal Aid to States (Regressions One to Four).

\begin{tabular}{|c|c|c|c|c|}
\hline \multirow{2}{*}{$\begin{array}{c}\text { Dependent Variable } \\
\text { Variable }\end{array}$} & \multicolumn{2}{|c|}{ Total Fundraising (mil \$) } & \multicolumn{2}{|c|}{ Share of Fundraising (\%) } \\
\hline & (1) & (2) & (3) & (4) \\
\hline $\begin{array}{l}\text { Challenger Fundraising } \\
\text { (in Millions of \$) }\end{array}$ & $\begin{array}{l}0.414^{* * *} \\
(0.047)\end{array}$ & $\begin{array}{c}0.401^{* * *} \\
(0.046)\end{array}$ & & \\
\hline $\begin{array}{l}\text { Cash on Hand } \\
\text { (in Millions of \$) }\end{array}$ & $\begin{array}{l}1.013^{* * *} \\
(0.180)\end{array}$ & $\begin{array}{l}0.919^{* * *} \\
(0.181)\end{array}$ & $\begin{array}{c}2.377^{* * *} \\
(0.468)\end{array}$ & $\begin{array}{c}2.357 * * * \\
(0.473)\end{array}$ \\
\hline $\begin{array}{l}\text { Total Pork Spending } \\
\text { (in Millions of \$) }\end{array}$ & $\begin{array}{l}-0.000 \\
(0.001)\end{array}$ & & $\begin{array}{l}-0.001 \\
(0.002)\end{array}$ & \\
\hline $\begin{array}{l}\text { Pork in Election Year } \\
\text { (in Millions of \$) }\end{array}$ & & $\begin{array}{l}0.017 * * \\
(0.008)\end{array}$ & & $\begin{array}{c}0.008 \\
(0.015)\end{array}$ \\
\hline $\begin{array}{l}\text { Pork Two Years Prior } \\
\text { (in Millions of \$) }\end{array}$ & & $\begin{array}{l}-0.008 \\
(0.009)\end{array}$ & & $\begin{array}{l}-0.003 \\
(0.020)\end{array}$ \\
\hline $\begin{array}{l}\text { Pork Four Years Prior } \\
\text { (in Millions of \$) }\end{array}$ & & $\begin{array}{c}0.002 \\
(0.007)\end{array}$ & & $\begin{array}{l}-0.015 \\
(0.016)\end{array}$ \\
\hline Previous Election Share & $\begin{array}{l}-0.235^{* * *} \\
(0.058)\end{array}$ & $\begin{array}{l}-0.231 * * * \\
(0.057)\end{array}$ & $\begin{array}{l}0.330 * * \\
(0.154)\end{array}$ & $\begin{array}{l}0.317^{* *} \\
(0.155)\end{array}$ \\
\hline Terms & $\begin{array}{c}0.050 \\
(0.330)\end{array}$ & $\begin{array}{l}-0.049 \\
(0.328)\end{array}$ & $\begin{array}{c}1.227 \\
(0.873)\end{array}$ & $\begin{array}{c}1.342 \\
(0.885)\end{array}$ \\
\hline Senators in Same Party? & $\begin{array}{l}-0.830 \\
(1.047)\end{array}$ & $\begin{array}{l}-1.230 \\
(1.044)\end{array}$ & $\begin{array}{l}7.699 * * * \\
(2.766)\end{array}$ & $\begin{array}{l}8.082 * * * \\
(2.817)\end{array}$ \\
\hline Female & $\begin{array}{l}3.267^{* * *} \\
(1.179)\end{array}$ & $\begin{array}{l}2.820 * * \\
(1.203)\end{array}$ & $\begin{array}{c}0.367 \\
(3.130)\end{array}$ & $\begin{array}{c}1.062 \\
(3.189)\end{array}$ \\
\hline Democrat & $\begin{array}{c}1.239 \\
(0.989)\end{array}$ & $\begin{array}{c}1.185 \\
(0.977)\end{array}$ & $\begin{array}{l}-0.793 \\
(2.539)\end{array}$ & $\begin{array}{l}-0.636 \\
(2.556)\end{array}$ \\
\hline 2004 Election & $\begin{array}{l}-2.083 \\
(1.803)\end{array}$ & $\begin{array}{c}-4.067 * \\
(2.075)\end{array}$ & & \\
\hline 2006 Election & $\begin{array}{l}-0.663 \\
(1.749) \\
\end{array}$ & $\begin{array}{l}-2.983 \\
(1.988) \\
\end{array}$ & & \\
\hline 2008 Election & $\begin{array}{l}-0.159 \\
(1.797)\end{array}$ & $\begin{array}{l}-2.626 \\
(2.013)\end{array}$ & & \\
\hline 2010 Election & $\begin{array}{l}-0.952 \\
(1.870)\end{array}$ & $\begin{array}{l}-2.447 \\
(2.103)\end{array}$ & & \\
\hline 2012 Election & $\begin{array}{c}-0.579 \\
(1.985)\end{array}$ & $\begin{array}{c}0.642 \\
(2.548)\end{array}$ & & \\
\hline 2014 Election & $\begin{array}{c}1.069 \\
(1.832)\end{array}$ & $\begin{array}{c}0.451 \\
(1.977)\end{array}$ & & \\
\hline 2016 Election & $\begin{array}{c}0.564 \\
(1.797)\end{array}$ & $\begin{array}{c}0.403 \\
(1.777)\end{array}$ & & \\
\hline Constant & $\begin{array}{c}21.743^{* * * *} \\
(3.656)\end{array}$ & $\begin{array}{c}22.371 * * * \\
(3.603)\end{array}$ & $\begin{array}{c}47.503^{* * * *} \\
(8.727)\end{array}$ & $\begin{array}{c}48.167^{* * *} \\
(8.733)\end{array}$ \\
\hline $\begin{array}{c}\text { Observations } \\
\text { R-squared } \\
\text { F-statistic }\end{array}$ & $\begin{array}{c}196 \\
0.494 \\
11.71^{* * *}\end{array}$ & $\begin{array}{c}196 \\
0.514 \\
11.06^{* * *}\end{array}$ & $\begin{array}{c}196 \\
0.256 \\
9.25 * * *\end{array}$ & $\begin{array}{c}196 \\
0.262 \\
7.35^{* * *}\end{array}$ \\
\hline
\end{tabular}

Dependent Variables

Regressions One to Two: Total Fundraising by Incumbent (in millions of \$) Regressions Three to Four: Percentage of Fundraising by Incumbent 
Table 3. Pooled OLS Regressions using Federal Aid to States (Regressions Five to Eight).

\begin{tabular}{|c|c|c|c|c|}
\hline \multirow{2}{*}{$\begin{array}{c}\text { Dependent Variable } \\
\text { Variable }\end{array}$} & \multicolumn{2}{|c|}{ Total Fundraising (Mil \$) } & \multicolumn{2}{|c|}{ Share of Fundraising (\%) } \\
\hline & (5) & (6) & (7) & (8) \\
\hline $\begin{array}{l}\text { Challenger Fundraising } \\
\text { (in Millions of \$) }\end{array}$ & $\begin{array}{c}0.763^{* * *} \\
(0.098)\end{array}$ & $\begin{array}{c}0.723^{* * *} \\
(0.085)\end{array}$ & & \\
\hline $\begin{array}{l}\text { Cash on Hand } \\
\text { (in Millions of \$) }\end{array}$ & $\begin{array}{l}1.060^{* * *} \\
(0.200)\end{array}$ & $\begin{array}{l}0.671^{* * *} \\
(0.189)\end{array}$ & $\begin{array}{c}2.331^{* * *} \\
(0.610)\end{array}$ & $\begin{array}{l}2.510^{* * *} \\
(0.663)\end{array}$ \\
\hline $\begin{array}{l}\text { Total Aid Spending } \\
\text { (in Millions of \$) }\end{array}$ & $\begin{array}{c}0.014 \\
(0.011)\end{array}$ & & $\begin{array}{l}-0.499 \\
(0.033)\end{array}$ & \\
\hline $\begin{array}{l}\text { Aid in Election Year } \\
\text { (in Millions of \$) }\end{array}$ & & $\begin{array}{l}-0.925^{* * *} \\
(0.299)\end{array}$ & & $\begin{array}{l}-0.354 \\
(0.915)\end{array}$ \\
\hline $\begin{array}{l}\text { Aid Two Years Prior } \\
\text { (in Millions of \$) }\end{array}$ & & $\begin{array}{c}0.738 \\
(0.586)\end{array}$ & & $\begin{array}{c}1.117 \\
(1.891)\end{array}$ \\
\hline $\begin{array}{l}\text { Aid Four Years Prior } \\
\text { (in Millions of \$) }\end{array}$ & & $\begin{array}{c}0.671 \\
(0.619)\end{array}$ & & $\begin{array}{l}-1.107 \\
(1.995)\end{array}$ \\
\hline Previous Election Share & $\begin{array}{c}-0.147^{* *} \\
(0.071)\end{array}$ & $\begin{array}{c}-0.103 * \\
(0.061)\end{array}$ & $\begin{array}{c}0.282 \\
(0.221)\end{array}$ & $\begin{array}{c}0.299 \\
(0.226)\end{array}$ \\
\hline Terms & $\begin{array}{l}-0.033 \\
(0.380)\end{array}$ & $\begin{array}{c}0.061 \\
(0.330)\end{array}$ & $\begin{array}{l}-0.393 \\
(1.205)\end{array}$ & $\begin{array}{l}-0.543 \\
(1.225)\end{array}$ \\
\hline Senators in Same Party? & $\begin{array}{c}2.104 \\
(1.375)\end{array}$ & $\begin{array}{c}1.215 \\
(1.187)\end{array}$ & $\begin{array}{c}10.043^{* *} \\
(4.263)\end{array}$ & $\begin{array}{l}9.806^{* *} \\
(4.337)\end{array}$ \\
\hline Female & $\begin{array}{l}1.113 \\
(1.514)\end{array}$ & $\begin{array}{l}-0.666 \\
(1.330)\end{array}$ & $\begin{array}{l}-6.574 \\
(4.771)\end{array}$ & $\begin{array}{l}-6.871 \\
(4.895)\end{array}$ \\
\hline Democrat & $\begin{array}{c}0.770 \\
(1.122)\end{array}$ & $\begin{array}{c}0.302 \\
(0.983)\end{array}$ & $\begin{array}{l}3.040 \\
(3.554)\end{array}$ & $\begin{array}{c}3.686 \\
(3.623)\end{array}$ \\
\hline 2004 Election & $\begin{array}{l}-0.774 \\
(1.580)\end{array}$ & $\begin{array}{l}-1.786 \\
(1.527)\end{array}$ & & \\
\hline 2006 Election & $\begin{array}{l}-0.178 \\
(1.526)\end{array}$ & $\begin{array}{l}-2.985^{*} \\
(1.600)\end{array}$ & & \\
\hline 2008 Election & $\begin{array}{c}0.915 \\
(1.568)\end{array}$ & $\begin{array}{l}-1.156 \\
(1.530)\end{array}$ & & \\
\hline Constant & $\begin{array}{l}11.750^{* * *} \\
(4.233)\end{array}$ & $\begin{array}{l}10.650 \\
(3.652)\end{array}$ & $\begin{array}{c}54.353^{* * * *} \\
(12.216)\end{array}$ & $\begin{array}{l}53.467 \\
(12.462)\end{array}$ \\
\hline $\begin{array}{c}\text { Observations } \\
\text { R-squared } \\
\text { F-statistic }\end{array}$ & $\begin{array}{c}101 \\
0.579 \\
11.11^{* * *}\end{array}$ & $\begin{array}{c}101 \\
0.693 \\
15.12\end{array}$ & $\begin{array}{c}101 \\
0.260 \\
4.66^{* * *}\end{array}$ & $\begin{array}{c}101 \\
0.258 \\
3.52 * * *\end{array}$ \\
\hline $\begin{array}{l}\text { Regressions I } \\
\text { Regression }\end{array}$ & $\begin{array}{r}\text { Depen } \\
\text { ix: Total Fu } \\
\text { to Eight: } \mathrm{Pe}\end{array}$ & $\begin{array}{l}\text { riables } \\
\text { g by Incum } \\
\text { e of Fundra }\end{array}$ & $\begin{array}{l}\text { n millions o } \\
\text { y Incumben }\end{array}$ & \\
\hline
\end{tabular}

This first set of results supports the three hypotheses laid out earlier. First, pork-barrel spending can be used to advertise and credit-claim, as it was shown to positively impact an incumbent's ability to fundraise. Second, that the timing of the pork-barrel appropriations matter, as pork-barrel spending appropriated during the election year had the largest impact. Third, general federal appropriations does not have the same impact on fundraising that pork-barrel spending does, which demonstrates that targeted expenditures is a potential tool that has powers that general aid spending does not.

\subsection{Panel Estimates of Fundraising with Pork-Barrel Spending}

Even though the pooled OLS results support the three hypotheses regarding the impact that pork-barrel spending and appropriation spending have on fundraising, a panel approach was used as a robustness check. I repeated the previous eight regressions using panel estimates. I continued to use the election year binary variables in order to control for the election year. For example, the years after the 2008 financial crisis would be associated with increased targeted and general spending, but donors may have had less income from which to make donations. 
Table 4 gives the estimates for regressions nine to 12. The results are similar to the estimates from regressions one to four, with only minor differences. First of all, the control variables in all four cases continued to behave similarly to the pooled OLS regressions. Again, challenger fundraising, service in the House of Representatives, the number of terms served, and being female are all significant and positively correlated with total fundraising. Second, the regressions utilizing the total incumbent fundraising variable continued to provide more robust results.

Table 4. Panel Regressions using Pork-Barrel Spending (Regressions Nine to 12).

\begin{tabular}{|c|c|c|c|c|}
\hline \multirow{2}{*}{$\begin{array}{c}\text { Dependent Variable } \\
\text { Variable }\end{array}$} & \multicolumn{2}{|c|}{ Total Fundraising (Mil \$) } & \multicolumn{2}{|c|}{ Share of Fundraising (\%) } \\
\hline & (9) & (10) & (11) & (12) \\
\hline $\begin{array}{l}\text { Challenger Fundraising } \\
\text { (in Millions of \$) }\end{array}$ & $\begin{array}{c}0.319^{* * *} \\
(0.044)\end{array}$ & $\begin{array}{c}0.302 * * * \\
(0.044)\end{array}$ & & \\
\hline $\begin{array}{l}\text { Cash on Hand } \\
\text { (in Millions of \$) }\end{array}$ & $\begin{array}{c}0.793^{* * *} \\
(0.259)\end{array}$ & $\begin{array}{l}0.632 * * \\
(0.262)\end{array}$ & $\begin{array}{c}2.880 * * * \\
(0.786)\end{array}$ & $\begin{array}{c}2.666 \\
(0.794)\end{array}$ \\
\hline $\begin{array}{l}\text { Total Pork Spending } \\
\text { (in Millions of \$) }\end{array}$ & $\begin{array}{l}0.002 * * \\
(0.001)\end{array}$ & & $\begin{array}{c}0.002 \\
(0.002)\end{array}$ & \\
\hline $\begin{array}{l}\text { Pork in Election Year } \\
\text { (in Millions of \$) }\end{array}$ & & $\begin{array}{l}0.017^{* *} \\
(0.007)\end{array}$ & & $\begin{array}{c}0.008 \\
(0.015)\end{array}$ \\
\hline $\begin{array}{l}\text { Pork Two Years Prior } \\
\text { (in Millions of \$) }\end{array}$ & & $\begin{array}{l}-0.006 \\
(0.009)\end{array}$ & & $\begin{array}{c}0.011 \\
(0.022)\end{array}$ \\
\hline $\begin{array}{l}\text { Pork Four Years Prior } \\
\text { (in Millions of \$) }\end{array}$ & & $\begin{array}{l}-0.005 \\
(0.006)\end{array}$ & & $\begin{array}{l}-0.015 \\
(0.018)\end{array}$ \\
\hline Previous Election Share & $\begin{array}{l}-0.185^{* * * *} \\
(0.056)\end{array}$ & $\begin{array}{l}-0.194^{* * *} \\
(0.056)\end{array}$ & $\begin{array}{c}0.035 \\
(0.181)\end{array}$ & $\begin{array}{c}0.028 \\
(0.183)\end{array}$ \\
\hline Terms & $\begin{array}{c}0.285 \\
(0.337)\end{array}$ & $\begin{array}{l}0.530^{*} \\
(0.334)\end{array}$ & $\begin{array}{c}0.728 \\
(1.048)\end{array}$ & $\begin{array}{c}1.031 \\
(1.041)\end{array}$ \\
\hline Senators in Same Party? & $\begin{array}{l}-1.050 \\
(1.178)\end{array}$ & $\begin{array}{l}-1.380 \\
(1.180)\end{array}$ & $\begin{array}{l}7.110^{*} \\
(3.728)\end{array}$ & $\begin{array}{c}6.368 \\
(3.797)\end{array}$ \\
\hline Female & $\begin{array}{l}4.813^{* * *} \\
(1.355)\end{array}$ & $\begin{array}{l}4.562^{* * *} \\
(1.359)\end{array}$ & $\begin{array}{l}3.515 \\
(4.306)\end{array}$ & $\begin{array}{c}3.252 \\
(4.351)\end{array}$ \\
\hline Democrat & $\begin{array}{c}1.321 \\
(1.308)\end{array}$ & $\begin{array}{c}0.729 \\
(1.290)\end{array}$ & $\begin{array}{l}6.880^{*} \\
(3.910)\end{array}$ & $\begin{array}{c}6.903 \\
(3.907)\end{array}$ \\
\hline 2004 Election & $\begin{array}{l}-3.971^{* * *} \\
(1.587)\end{array}$ & $\begin{array}{l}-5.752^{* * *} \\
(2.003)\end{array}$ & & \\
\hline 2006 Election & $\begin{array}{l}-2.442 * \\
(1.432)\end{array}$ & $\begin{array}{l}-3.842^{* *} \\
(1.894)\end{array}$ & & \\
\hline 2008 Election & $\begin{array}{l}-0.209 \\
(1.609)\end{array}$ & $\begin{array}{l}-1.994 \\
(2.050)\end{array}$ & & \\
\hline 2010 Election & $\begin{array}{l}-1.256 \\
(1.675) \\
\end{array}$ & $\begin{array}{l}-2.102 \\
(2.107) \\
\end{array}$ & & \\
\hline 2012 Election & $\begin{array}{l}-1.804 \\
(1.658)\end{array}$ & $\begin{array}{c}0.179 \\
(2.339)\end{array}$ & & \\
\hline 2014 Election & $\begin{array}{c}1.199 \\
(1.701)\end{array}$ & $\begin{array}{l}1.440 \\
(1.874)\end{array}$ & & \\
\hline 2016 Election & $\begin{array}{l}-1.339 \\
(1.618)\end{array}$ & $\begin{array}{l}-1.889 \\
(1.623)\end{array}$ & & \\
\hline Constant & $\begin{array}{c}18.689^{* * *} \\
(3.539)\end{array}$ & $\begin{array}{c}20.903 * * * \\
(3.470)\end{array}$ & $\begin{array}{c}59.141 * * * \\
(10.728)\end{array}$ & $\begin{array}{c}60.969 \\
(10.562)\end{array}$ \\
\hline $\begin{array}{c}\text { Observations } \\
\text { R-squared } \\
F \text {-statistic }\end{array}$ & $\begin{array}{c}196 \\
0.497 \\
8.62^{* * *}\end{array}$ & $\begin{array}{c}196 \\
0.507 \\
7.81^{* * *}\end{array}$ & $\begin{array}{c}196 \\
0.198 \\
3.56^{* * * *}\end{array}$ & $\begin{array}{c}196 \\
0.167 \\
2.81^{* * *}\end{array}$ \\
\hline $\begin{array}{c}\text { Regression } \\
\text { Regres }\end{array}$ & $\begin{array}{l}\text { Depen } \\
\text { Total Fun } \\
\text { 12: Percer }\end{array}$ & $\begin{array}{l}\text { ariables } \\
\text { by Incumb } \\
\text { f Fundraisin }\end{array}$ & $\begin{array}{l}\text { Millions of } \\
\text { cumbent }\end{array}$ & \\
\hline
\end{tabular}

Again, pork-barrel spending influences fundraising, but only when properly timed. Specifically, when $\$ 1$ million worth of pork-barrel money is brought into the state during the senator's election year, the senator is able to increase their fundraising by $\$ 17,000$; that is, an additional dollar of fundraising costs around $\$ 60$ worth of pork-barrel money. A key difference between the panel results 
and pooled OLS results is that total pork-barrel spending is significant and positively correlated with total fundraising. This indicates that pork-barrel spending throughout a senator's entire term does have a net positive effect on their fundraising. Additionally, pork-barrel spending continues to influence the percent of fundraising by the incumbent, but only when properly timed.

\subsection{Panel Estimates of Fundraising with Federal Aid}

I continue the analysis by repeating the four fundraising regressions with a fixed-effects panel estimation. Recall that this set of regressions utilized the federal aid variables instead of the pork-barrel spending variables.

Table 5 gives the estimates for regressions 13 to 16. Again, the results are similar to the estimates from regressions five to eight. The main difference is that the results are not as robust as the pooled OLS estimates.

Table 5. Panel Regressions using Federal Aid (Regressions 13-16).

\begin{tabular}{|c|c|c|c|c|}
\hline \multirow{2}{*}{$\begin{array}{c}\text { Dependent Variable } \\
\text { Variable }\end{array}$} & \multicolumn{2}{|c|}{ Total Fundraising (Mil \$) } & \multicolumn{2}{|c|}{ Share of Fundraising (\%) } \\
\hline & (13) & (14) & (15) & (16) \\
\hline $\begin{array}{l}\text { Challenger Fundraising } \\
\text { (in Millions of \$) }\end{array}$ & $\begin{array}{l}0.651 * * * \\
(0.110)\end{array}$ & $\begin{array}{l}0.665^{* * *} \\
(0.090)\end{array}$ & & \\
\hline $\begin{array}{l}\text { Cash on Hand } \\
\text { (in Millions of \$) }\end{array}$ & $\begin{array}{c}0.270 \\
(0.342)\end{array}$ & $\begin{array}{c}0.145 \\
(0.282)\end{array}$ & $\begin{array}{l}3.379 * * * \\
(1.268)\end{array}$ & $\begin{array}{l}3.267 * * \\
(1.284)\end{array}$ \\
\hline $\begin{array}{l}\text { Total Aid Spending } \\
\text { (in Millions of \$) }\end{array}$ & $\begin{array}{l}-0.008 \\
(0.026)\end{array}$ & & $\begin{array}{l}-0.022 \\
(0.099)\end{array}$ & \\
\hline $\begin{array}{l}\text { Aid in Election Year } \\
\text { (in Millions of \$) }\end{array}$ & & $\begin{array}{l}-1.737^{* * *} \\
(0.242)\end{array}$ & & $\begin{array}{l}-0.661 \\
(1.042)\end{array}$ \\
\hline $\begin{array}{l}\text { Aid Two Years Prior } \\
\text { (in Millions of \$) }\end{array}$ & & $\begin{array}{c}1.081 \\
(0.851)\end{array}$ & & $\begin{array}{c}0.190 \\
(4.064)\end{array}$ \\
\hline $\begin{array}{l}\text { Aid Four Years Prior } \\
\text { (in Millions of \$) }\end{array}$ & & $\begin{array}{c}0.385 \\
(0.665)\end{array}$ & & $\begin{array}{l}-0.393 \\
(2.964)\end{array}$ \\
\hline Previous Election Share & $\begin{array}{l}-0.141 \\
(0.010)\end{array}$ & $\begin{array}{l}-0.079 \\
(0.081)\end{array}$ & $\begin{array}{l}-0.223 \\
(0.399)\end{array}$ & $\begin{array}{l}-0.123 \\
(0.410)\end{array}$ \\
\hline Terms & $\begin{array}{c}0.596 \\
(0.500)\end{array}$ & $\begin{array}{c}0.545 \\
(0.406)\end{array}$ & $\begin{array}{l}-0.168 \\
(1.978)\end{array}$ & $\begin{array}{l}-0.084 \\
(2.005)\end{array}$ \\
\hline Senators in Same Party? & $\begin{array}{l}3.237 \\
(2.492)\end{array}$ & $\begin{array}{c}2.748 \\
(2.026)\end{array}$ & $\begin{array}{c}8.823 \\
(9.973)\end{array}$ & $\begin{array}{c}7.597 \\
(10.166)\end{array}$ \\
\hline Female & $\begin{array}{l}4.334^{*} \\
(2.370)\end{array}$ & $\begin{array}{l}3.807 * * \\
(1.901)\end{array}$ & $\begin{array}{c}-13.179 \\
(9.268)\end{array}$ & $\begin{array}{c}-13.632 \\
(9.102)\end{array}$ \\
\hline Democrat & $\begin{array}{l}-1.906 \\
(2.133)\end{array}$ & $\begin{array}{l}-1.649 \\
(1.733)\end{array}$ & $\begin{array}{c}7.020 \\
(8.075)\end{array}$ & $\begin{array}{c}6.904 \\
(8.245)\end{array}$ \\
\hline 2004 Election & $\begin{array}{l}-1.251 \\
(1.486)\end{array}$ & $\begin{array}{c}-3.005^{* *} \\
(1.480)\end{array}$ & & \\
\hline 2006 Election & $\begin{array}{c}-0.197 \\
(1.668)\end{array}$ & $\begin{array}{c}-3.883^{* *} \\
(1.598)\end{array}$ & & \\
\hline 2008 Election & $\begin{array}{c}1.690 \\
(1.550)\end{array}$ & $\begin{array}{l}-1.005 \\
(1.514)\end{array}$ & & \\
\hline Constant & $\begin{array}{c}12.236^{* *} \\
(5.857)\end{array}$ & $\begin{array}{l}10.174^{*} \\
(5.863)\end{array}$ & $\begin{array}{c}81.996^{* * *} \\
(22.321)\end{array}$ & $\begin{array}{c}83.693 \text { *** } \\
(26.403)\end{array}$ \\
\hline $\begin{array}{l}\text { Observations } \\
\text { R-squared } \\
\text { F-statistic }\end{array}$ & $\begin{array}{c}101 \\
0.598 \\
5.55^{* * *}\end{array}$ & $\begin{array}{c}101 \\
0.749 \\
8.97 * * *\end{array}$ & $\begin{array}{c}101 \\
0.181 \\
1.41\end{array}$ & $\begin{array}{c}101 \\
0.200 \\
1.19\end{array}$ \\
\hline $\begin{array}{r}\text { Regression } \\
\text { Regres }\end{array}$ & $\begin{array}{l}\text { Depen } \\
\text { Total Fun } \\
\text { o 16: Perce }\end{array}$ & $\begin{array}{l}\text { ariables } \\
\text { g by Incumb } \\
\text { f Fundraisin }\end{array}$ & $\begin{array}{l}\text { millions of } \\
\text { cumbent }\end{array}$ & \\
\hline
\end{tabular}

Standard Errors in Parentheses: ${ }^{* * *}=1 \%,{ }^{* *}=5 \%,{ }^{*}=10 \%$ Significance Level. 


\section{Discussion}

Overall, the above results support the three hypotheses stated at the beginning of the paper. First, pork-barrel spending can have a positive and significant impact on fundraising. Second, the timing of the pork-barrel spending matters. To be specific, only pork-barrel spending in the election year seems to have an impact on campaign contributions. Third, the relationship between federal aid to states and incumbent fundraising is ambiguous; however, it is clear that the amount of fundraising per dollar of pork-barrel spending is far greater than the amount of fundraising per dollar of federal aid. This suggests that legislators should prefer pork-barrel spending over general appropriations for their states, possibly because the former is more visible and easier to take credit for. It would be difficult for a single senator to claim credit for a change in the entire Women, Infant, and Children (WIC) system (unless they were actually responsible for a major change, but this is rare). However, a senator could claim credit for a new highway, park, museum, or federal building in their state. This also lends support to universalism hypothesis of Weingast (1994), which stated that politicians are likely to work together on targeted spending bills, because it is in their respective fundraising interests to do so. This shows that pork-barrel spending is used as a source of political capital for both politicians and political entrepreneurs.

There are several variables that were not included in this study. First, some studies use per-capita measures. This is problematic for several reasons. First, it does not allow for a simple interpretation of the estimates. Instead of being able to estimate the number of dollars needed to increase fundraising by $\$ 1$, all of the values are based on the size of the population. More importantly, estimates of per capita campaign spending are very weak.

Another possible change that could be made is to compare similar spending types. For example, I could have compared the impact of pork-barrel spending when included in a transportation omnibus bill compared to the impact of federal spending by the Department of Transportation. As previously mentioned, senators have much less control over the amount of money spent by executive agencies of the government. Therefore, incumbents can use pork-barrel spending to steer money to projects that they believe will provide a greater personal benefit.

\section{Conclusions}

We again return to the work of (Mayhew 1974) and the tools utilized by members of Congress to win re-election. This paper has demonstrated that incumbent senators can use their position to appropriate targeted expenditures in return for political contributions. This allows senators to engage in both credit-claiming and advertising. By taking credit for the pork-barrel money, they can use the subsequent campaign donations to enhance the amount of advertising possible, further increasing the likelihood of being re-elected. This also leads credence to the idea that political entrepreneurs are able to manipulate incumbents, especially those in vulnerable seats. They can accomplish this by rewarding incumbents with campaign dollars for targeted expenditures that directly benefit the political entrepreneurs.

By extending past research by Krebs (2001), Samuels (2002), Bonneau (2007), and Stratmann (2013), I was able to model and estimate an incumbent senator's ability to fundraise for re-election. The main novelty of the above estimates was the use of disaggregated pork-barrel appropriations. This furthers the existing literature pertaining to the motivation that incumbents have to use a type of funding that is often said to be inefficient.

In addition, the results are robust, as similar estimates are obtained using pooled OLS estimates and fixed-effect panel estimates. The results also suggest that state federal appropriations may increase fundraising by senators, although less so than targeted expenditures. This supports the hypothesis that legislators prefer to use pork-barrel spending, all other things being equal, because the results are more visible, easier to take credit for, and easier to direct to certain parties. Finally, as discussed earlier, there is evidence that pork-barrel spending is used as political capital. 
This evidence also supports the claim that pork-barrel spending is used as a currency in the world of political capitalism. Incumbents steer federal money to states and districts to support localized projects. These projects directly benefit the particular businesses that win contracts associated with the appropriation. The business owners then reward the incumbents with campaign donations, which can be used to bolster their likelihood of re-election.

Funding: This research received no external funding.

Conflicts of Interest: The author declares no conflict of interest.

\section{References}

Boas, Taylor, Daniel Hidalgo, and Neal Richardson. 2014. The spoils of victory: Campaign donations and government contracts in Brazil. The Journal of Politics 76: 415-29. [CrossRef]

Bonneau, Chris. 2007. Campaign fundraising in state supreme court elections. Social Science Quarterly 88: 68-85. [CrossRef]

Dawson, Paul, and James Zinser. 1976. Political finance and participation in congressional elections. The Annals of the American Academy of Political and Social Science 425: 59-73. [CrossRef]

Freedman, Eric, and Frederick Fico. 2005. Male and Female Sources in Newspaper Coverage of Male and Female Candidates in Open Races for Governor in 2002. Mass Communication and Society 8: 257-72. [CrossRef]

Hayes, Danny, and Jennifer Lawless. 2015. A Non-Gendered Lens? Media, Voters, and Female Candidates in Contemporary Congressional Elections. Perspective on Politics 13: 95-118. [CrossRef]

Holcombe, Randall. 2002. Political entrepreneurship and the democratic allocation of economic resources. The Review of Austrian Economics 15: 143-59. [CrossRef]

Holcombe, Randall. 2015. Political capitalism. Cato Journal 35: 41-66.

Jacobson, Gary. 1981. Strategy and Choice in Congressional Elections. New Haven: Yale University Press.

Jacobson, Gary. 1990. The Effects of Campaign Spending in House Elections: New Evidence for Old Arguments. American Journal of Political Science 34: 334-62. [CrossRef]

Krebs, Timothy. 2001. Political experience and fundraising in city council elections. Social Science Quarterly 82: 536-51. [CrossRef]

Krieger, Gustavo, Fernando Rodrigues, and Elvis Bonassa. 1994. Os donos do Congresso: A farsa na CPI do Orcamento. Sao Paulo: Editora Atica.

Krueger, Anne. 1974. The Political Economy of the Rent-Seeking Society. American Economic Review 64: 291-303.

Laband, David, and John Sophocleus. 1988. The social cost of rent-seeking: First estimates. Public Choice 58: 269-75. [CrossRef]

Lopez, Edward. 2002. The legislator as political entrepreneur: Investment in political capital. The Review of Austrian Economics 15: 211-28. [CrossRef]

Mayhew, David. 1974. Congress: The Electoral Connection. New Haven: Yale University Press.

McCaffrey, Matthew, and Joseph Salerno. 2011. A theory of political entrepreneurship. Modern Economy 2: 552-60. [CrossRef]

Milyo, Jeffrey. 1999. The political economics of campaign finance. The Independent Review 3: 537-457.

Mixon, Franklin, and David Hobson. 2001. Intergovernmental grants and the positioning of presidential primaries and caucuses: Empirical evidence from the 1992, 1996, and 2000 election cycles. Contemporary Economic Policy 19: 27-38. [CrossRef]

Mixon, Franklin, David Laband, and Robert Ekelund. 1994. Rent seeking and hidden in-kind resource distortion: Some empirical evidence. Public Choice 78: 171-75. [CrossRef]

Palda, Kristian. 1973. Does advertising influence votes? An analysis of the 1966 and 1970 Quebec elections. Canadian Journal of Political Science 6: 638-55. [CrossRef]

Palda, Kristian. 1975. The Effect of Expenditures on Political Success. Journal of Law and Economics 18: 745-71. [CrossRef]

Payne, Marissa. 2014. Five sad and shocking facts about World Cup corruption in Brazil. The Washington Post, May 12.

Posner, Richard. 1975. The social costs of monopoly and regulations. Journal of Political Economy 83: 807-27. [CrossRef] 
Rogers, James. 2002. Free Riding in State Legislatures. Public Choice 113: 59-76. [CrossRef]

Samuels, David. 2002. Pork barreling is not credit claiming of advertising: Campaign finance and the sources of the personal vote in Brazil. The Journal of Politics 64: 845-63. [CrossRef]

Schneider, Mark, and Paul Teske. 1992. Toward a theory of the political entrepreneur: Evidence from local government. American Political Science Review 85: 737-47. [CrossRef]

Sobel, Russell, and Thomas Garrett. 2002. On the measurement of rent seeking and its social opportunity cost. Public Choice 112: 115-36. [CrossRef]

Stratmann, Tomas. 1995. Some talk: Money in politics. A (partial) review of the literature. Public Choice 124: 135-56. [CrossRef]

Stratmann, Tomas. 2013. The effects of earmarks on the likelihood of reelection. European Journal of Political Economy 32: 341-55. [CrossRef]

Tullock, Gordon. 1967. The welfare costs of tariffs, monopolies, and theft. Western Economic Journal 5: $224-32$. [CrossRef]

Tullock, Gordon, James Buchanan, and Robert Tollison. 1980. Efficient Rent-Seeking in Toward a Theory of the Rent-Seeking Society. College Station: Texas A\&M Press, pp. 97-112.

Uhlaner, Carole, and Kay Schlozman. 1986. Candidate gender and congressional campaign receipts. The Journal of Politics 48: 30-50. [CrossRef]

Weingast, Barry. 1994. Reflections on Distributive Politics and Universalism. Political Research Quarterly 47: 319-27. [CrossRef]

Welch, William. 1974. The economics of campaign funds. Public Choice 20: 83-97. [CrossRef]

Welch, William. 1976. The effectiveness of expenditures in state legislative races. American Politics Quarterly 4: 333-56. [CrossRef]

(C) 2019 by the author. Licensee MDPI, Basel, Switzerland. This article is an open access article distributed under the terms and conditions of the Creative Commons Attribution (CC BY) license (http:/ / creativecommons.org/licenses/by/4.0/). 